\title{
UJI KOMBINASI ANTIDIABETIK ANTARA EKSTRAK KULIT DURIAN DAN ACARBOSE DENGAN PERHITUNGAN COMBINATION INDEX DALAM PENGHAMBATAN KERJA ENZIM $\alpha$-AMILASE
}

\section{ANTIDIABETIC STUDY OF COMBINATION OF DURIAN EPICARPS EXTRACT AND ACARBOSE BY DETERMINATION OF COMBINATION INDEX IN INHIBITION OF $\alpha$-AMYLASE}

\author{
Mahfur, Muhammad Walid \\ Program Studi S1 Farmasi, Fakultas Farmasi, Universitas Pekalongan \\ Jl. Sriwijaya No. 3, Pekalongan, Indonesia Telp. (0285) 426800 \\ Email: mahfur.isfa@gmail.com (Mahfur)
}

\begin{abstract}
ABSTRAK
Hiperglikemia adalah suatu gangguan metabolisme yang ditandai dengan meningkatnya kadar gula darah melebihi batas normal (> $120 \mathrm{mg} / \mathrm{dL}$ ). Pengelolaan dan pencegahan DM dilakukan melalui pengaturan kadar glukosa yang baik. Terapi menggunakan obat sintetis seperti acarbose memiliki efek samping yang merugikan salah satunya adalah gangguan fungsi hati. Terapi dengan menggunakan obat alam juga memiliki kelemahan yaitu dosis penggunaan yang sangat besar untuk mencapai target terapi. Penelitian ini bertujuan untuk melihat efek kombinasi antara ekstrak kulit durian dan acarbose dengan perhitungan combination index dalam penghambatan enzim $\alpha$-amilase. Metode penelitian ini termasuk dalam metode penelitian eksperimental. Diawali dengan pembuatan ekstrak etanol kulit durian dengan metode maserasi, pengujian efek antidiabetik dalam penghambatan kerja enzim $\alpha$-amilase, dilanjutkan dengan perhitungan combination index menggunakan software compusyn. Ekstraksi yang dilakukan memperoleh rendemen sebesar $14,96 \%$. Selanjutnya ekstrak tersebut diuji daya hambatnya terhadap enzim $\alpha$-amilase, dimana nilai $I_{50}$ yang dihasilkan sebesar $731,05 \mathrm{ppm}$. Daya hambat acarbose terhadap enzim $\alpha$-amilase menunjukkan $\mathrm{IC}_{50}$ yang diperoleh sebesar $0,45 \mathrm{ppm}$. $\mathrm{IC}_{50}$ yang diperoleh menjadi landasan dalam menentukan besaran konsentrasi dari masing masing zat aktif yang akan dikombinasikan. Hasil perhitungan combination index antara ekstrak etanol kulit durian dan acarbose diperoleh $>1$, sehingga termasuk dalam kategori antagonis.
\end{abstract}

Kata kunci: acarbose, antidiabetic, $\alpha$-amilase, kulit durian.

\section{ABSTRACT}

Hyperglycemia is a disorder characterized by blood sugar levels that exceed the normal limit (> $120 \mathrm{mg} / \mathrm{dL}$ ). Management of diabetes mellitus (DM) can be done through keeping the blood sugar level within the normal range. DM therapy using synthetic 
drugs, such as acarbose, has demonstrated adverse side effects, including liver dysfunction. DM therapy using standalone natural products also had the disadvantage, that it needed a very large doses to reach the target of therapy. This study aimed to evaluate the effects of combination of durian epicarps extract and acarbose, by calculating their combination index in inhibiting alpha-amylase enzyme. This study used the experimental research method. Ethanol extract of durian epicarps was prepared by maceration method. The anti-diabetic activity of the extract was evaluated using $\alpha$ amylase inhibitory method. The calculation of the combination index utilized compusyn software. The extraction yield was $14.96 \%$. The extract demonstrated the inhibitory effect on the $\alpha$-amylase with $I C_{50}$ value of $731.05 \mathrm{ppm}$, while that of acarbose was 0.45 ppm. The combination index between ethanol extract of durian epicarps and acarbose was $>1$, hence their combination was in the antagonist category.

Key words: acarbose, $\alpha$-amilase, antidiabetic, combination index, Durio zibethinus. 


\section{Pendahuluan}

Hiperglikemia adalah suatu gangguan metabolisme yang ditandai dengan meningkatnya kadar gula darah melebihi batas normal (> $120 \mathrm{mg} / \mathrm{dL}$ ). Gangguan tersebut dikarenakan adanya kelainan sekresi insulin, kerja insulin, atau keduanya (Perkeni, 2011). Hiperglikemia menyebabkan banyak penyakit, salah satu di antaranya adalah diabetes melitus. Organisasi Kesehatan Dunia (WHO, 2013) menyatakan diabetes melitus diderita oleh $10 \%$ orang dewasa dunia. Oleh karena itu kini penyakit diabetes melitus mendapat banyak perhatian dari berbagai pihak dalam upaya pencegahan dan pengelolaan.

Pengelolaan dan pencegahan komplikasi pada penderita DM dilakukan melalui pengaturan kadar glukosa yang baik dengan terapi nonfarmakologis maupun farmakologis. Terapi nonfarmakologis dengan cara memperbaiki asupan makanan yang dikonsumsi, dan memperbaiki gaya hidup dari penderita diabetes melitus seperti tidak merokok, tidak minum minuman keras. Terapi farmakologis untuk diabetes melitus dengan memberikan obat-obat penurun glukosa darah, meliputi glibenklamida, acarbose, metformin, atau bisa dengan pemberian obat alam yang bisa menurunkan kadar gula dalam darah.

Penggunaan obat antidiabetes kebanyakan berlangsung lama dan menimbulkan efek samping yang tidak diinginkan serta tingginya biaya pengobatan sehingga diperlukan alternatif terapi untuk mengurangi timbulnya beberapa efek samping dan biaya pengobatan. Salah satunya dengan memanfaatkan tanaman yang diketahui berkhasiat hipoglikemik yang berada di sekitar kita. Pada tahun 1980, WHO merekomendasikan agar dilakukan penelitian terhadap tanaman yang memiliki efek hipoglikemik karena penggunaan obat-obat hipoglikemik yang kurang aman (Kasiviswanath et al., 2005). Salah satu alternatifnya adalah kulit durian.

Kulit durian mengandung fitonutrien yang dilaporkan dapat menstabilkan gula darah. Fitonutrien tersebut antara lain mangan, organosulfur, dan metabolit sekunder (Santoso, 2012). Namun kulit durian kurang termanfaatkan bahkan menjadi limbah yang dapat menyebabkan pencemaran lingkungan.

Terapi farmakologis baik menggunakan obat sintetis maupun obat 
alam masing-masing memiliki kelemahan. Terapi menggunakan obat sintetis seperti acarbose memiliki efek samping yang merugikan salah satunya adalah gangguan fungsi hati. Terapi dengan menggunakan obat alam juga memiliki kelemahan yaitu dosis penggunaan yang sangat besar untuk mencapai target terapi. Oleh karena hal tersebut perlu adanya alternatif dari terapi diabetes melitus dengan melakukan kombinasi antara obat sintetis dan juga obat alam tersebut.

\section{Metode Penelitian}

Penelitian ini dikategorikan sebagai penelitian eksperimental. Design penelitian ini adalah design penelitian yang memberikan perlakuan (intervensi) pada objek penelitian yang dibandingkan dengan group kontrol.

\section{Alat dan Bahan}

Alat-alat yang digunakan adalah seperangkat alat maserasi, propipet, pipet tetes, pipet volume, alat-alat gelas (Pyrex), neraca analitik, rotary evaporator (Biobase RE2000B), corong buchner, cawan penguap, batang pengaduk, stirer, water bath, spektrofotometri UV-Vis (Genesis). Bahan yang digunakan adalah amilum, kulit durian, etanol $70 \%, \mathrm{HCl}$, buffer $\mathrm{pH}$ 7, akuades, enzim $\alpha$-amilase.

Jalannya Penelitian

1. Pembuatan ekstrak etanol kulit durian

Sebanyak 30 gram simplisia ditambahkan $300 \mathrm{~mL}$ pelarut, yaitu etanol $70 \%$. Sampel direndam selama 24 jam lalu disaring kemudian diremaserasi. Proses ekstraksi dilakukan selama 3 hari dan 2 kali pengulangan. Filtrat yang diperoleh dipekatkan dengan evaporator hingga diperoleh ekstrak kental.

2. Uji aktivitas antidiabetik dengan penghambatan kerja enzim $\alpha$-amilase

Larutan pati (substrat) dibuat dengan konsentrasi $10 \mathrm{mg} / \mathrm{ml}$. Masing-masing konsentrasi diambil 3,5 ml, ditambahkan 3,5 $\mathrm{ml}$ buffer fosfat pH 7 pada tabung reaksi. Blanko berupa campuran akuades dan buffer fosfat $\mathrm{pH} 7$ disiapkan sebanyak $7 \mathrm{ml}$. Pada larutan pati ditambahkan $1 \mathrm{ml}$ enzim $\alpha$-amilase. Larutan pati dan blanko diinkubasi 37 ${ }^{\circ} \mathrm{C}$ selama 30 menit. $\mathrm{HCl} 1 \mathrm{~N}$ ditambahkan sebanyak $1 \mathrm{ml}$. Larutan iodine (yang sudah diencerkan 100x) ditambahkan $1 \mathrm{ml}$. Jika keruh atau terbentuk gumpalan, disaring terlebih dahulu. Hasil penyaringan ditera absorbansinya pada panjang 
gelombang $620 \mathrm{~nm}$. Dari hasil uji terhadap aktifitas enzim dengan tersebut dicari \% penghambatan rumus seperti pada Persamaan 1.

$$
\text { \% Penghambotan }=\frac{\text { absorbansi sampel }- \text { absorbansi blanko } \mathrm{X} 100 \%}{\text { absorbansi blanko }}
$$

3. Uji kombinasi antara ekstrak etanol kulit durian dan acarbose

Dibuat seri konsentrasi sampel dan acarbose untuk perlakuan (termasuk kontrol). Seri konsentrasi terdiri dari 4 konsentrasi yaitu IC50, 3/4 IC50 , 1/2 IC50, dan 1/4 IC50 (Anindyajati, et al., 2010). Kemudian masingmasing dari konsentrasi tersebut diuji daya hambat enzim $\alpha$-amilasenya. Kemudian combination index dihitung dengan metode compusyn menggunakan software compusyn.

\section{Hasil dan Pembahasan}

1. Pembuatan ekstrak etanol kulit durian

Ekstrak etanol kulit durian dibuat dengan metode maserasi yaitu dengan cara perendaman dan pengadukan serbuk kulit durian menggunakan cairan penyari etanol 70\% selama 24 jam. Pertimbangan menggunakan pelarut etanol $70 \%$ ini berdasarkan sifat etanol yang semipolar sehingga menguntungkan untuk menyari senyawa-senyawa yang sifatnya polar sampai nonpolar, termasuk di antaranya adalah senyawa flavonoid, yang mempunyai aktifitas inhibisi teradap aktifitas enzim $\alpha$-amylase ataupun enzim glukosidase (Jaitrong et al., 2009). Selain itu etanol juga dipilih karena mempunyai sifat nontoksik dan dapat berfungsi sebagai pengawet karena etanol juga dapat membunuh bakteri (antiseptik). Berat rendemen ekstrak yang diperoleh dapat dilihat pada Tabel 1.

Tabel 1. Berat rendemen ekstrak etanol kulit durian

\begin{tabular}{lc}
\hline Keterangan & Ekstrak Etanol Kulit Durian \\
\hline Berat serbuk & $250 \mathrm{~g}$ \\
Berat ekstrak & $37,4 \mathrm{~g}$ \\
Rendemen & $14,96 \%$ \\
\hline
\end{tabular}


2. Pembuatan kurva kalibrasi amilum Amilum merupakan salah satu jenis karbohidrat polisakarida (Murray et al., 2009) yang sering menjadi bahan pokok makanan sehari hari. Tahapan metabolism karbohidrat dalam tubuh diawali dengan dipecahnya senyawa karbohidrat terutama polisakarida menjadi senyawa yang lebih sederhana (monosakarida atau disakarida) (Murray et al., 2009). Katabolisme yang terjadi pada karbohidrat dibantu oleh adanya enzim $\alpha$-amilase, $\beta$-glukosidase, dan $\beta$-amilase (Cummings dan Mann, 2009).

Pembuatan kurva kalibrasi amilum menghasilkan persamaan $\mathrm{y}=$ $0,0357 x-0,0042$ dengan nilai $R=$ 0,9865. Kurva kalibrasi yang diperoleh dapat dilihat pada Gambar 1.

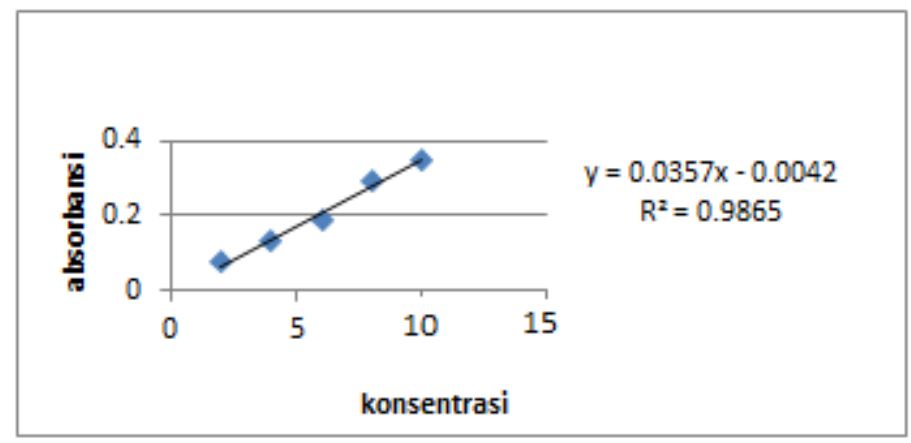

Gambar 1. Kurva kalibrasi amilum.

3. Aktifitas enzim $\alpha$-amilase terhadap amilum

Enzim $\alpha$-amilase adalah enzim yang mengkatalisis hidrolisis dari $\alpha$ 1,4-glikosidik amilosa pati (polisakarida) menjadi senyawa polisakarida yang lebih sederhana yaitu glukosa (monosakarida). Enzim $\alpha$-amilase terdapat pada kelenjar ludah serta pada dinding usus halus, dan juga pada pankreas. Enzim-enzim $\alpha$-amilase berfungsi untuk menghidrolisis oligosakarida pada dinding usus halus. Katalisis yang dilakukan oleh enzim $\alpha$-amilase merupakan tahap awal proses metabolisme karbohidrat. Setelah pemecahan tersebut terjadi, glukosa akan dimetabolisme ke tahap selanjutnya sampai menghasilkan energi dan cadangan makanan. 
Aktifitas enzim $\alpha$-amilase dilihat dari nilai absorbansi sampel yang menurun jika dibandingkan dengan absorbansi amilum saja. Hasil penelitian menunjukkan bahwa enzim $\alpha$-amilase mempunyai aktifitas, ditunjukkan dengan adanya penurunan absorbansi. Penurunan absorbansi tersebut dikarenakan adanya pemecahan amilum oleh enzim $\alpha$-amilase menjadi glukosa, sehingga amilum yang terbaca pada serapan tersebut sedikit. Dalam metabolism tubuh, fenomena tadi membuat kadar glukosa dalam darah menjadi lebih tinggi. Oleh karena hal tersebut aktifitas enzim $\alpha$-amilase perlu dihambat agar pemecahan amilum menjadi glukosa bisa dihindari.

4. Uji daya hambat ekstrak etanol kulit durian pada aktifitas enzim

Uji daya hambat ekstrak etanol kulit durian ini dilakukan untuk mengetahui aktifitas inhibitor ekstrak dalam menghambat kinerja enzim $\alpha$ amilase. Mekanisme inhibitor suatu senyawa terhadap kinerja enzim terbagi menjadi 3 golongan yaitu inhibitor kompetitif, inhibitor nonkompetitif, dan inhibitor ganda (Nelson dan Cox, 2008). Kulit durian adalah salah satu tanaman yang mengandung banyak metabolit sekunder. Berdasarkan penelitian Anggraeni dan Anam (2016), serbuk kulit durian mengandung senyawa saponin, flavonoid, alkaloid, steroid, tannin, dan quinon. Kandungan metabolit sekunder tersebut merupakan senyawa yang memiliki aktifitas terapi, adapun yang memiliki aktifitas daya hambat terhadap enzim $\alpha$-amilase adalah flavonoid dan turunannya (Elmaniar, 2017). Mekanisme kerja dari senyawa inhibitor tersebut adalah dengan berperan untuk mengikat dan menginaktifkan enzim $\alpha$-amilase. Penghambatan terhadap enzim $\alpha$ amilase dapat menunda dan memperlama waktu cerna karbohidrat, menyebabkan penurunan laju absorbsi glukosa, dan mencegah peningkatan kadar plasma glukosa postpandrial (Sales et al., 2012).

Pengujian daya hambat ekstrak etanol terhadap enzim $\alpha$-amilase dilakukan dengan menambahkan seri konsentrasi ekstrak etanol kulit durian yaitu dari $25,50,100,500$, dan 1000 ppm. Hasil pengujian daya hambat ditunjukkan dari turunnya 
nilai absorbansi dibandingkan dengan

enzim dan substrat (blanko).

Absorbansi yang diperoleh

selanjutnya digunakan untuk

menghitung \% inhibisi (daya hambat)

ekstrak etanol kulit durian terhadap enzim $\alpha$-amilase. Grafik antara konsentrasi ekstrak vs \% inhibisi enzim dapat dilihat pada Gambar 2. Nilai IC $_{50}$ ekstrak etanol kulit durian yang diperoleh adalah 731,05 ppm.

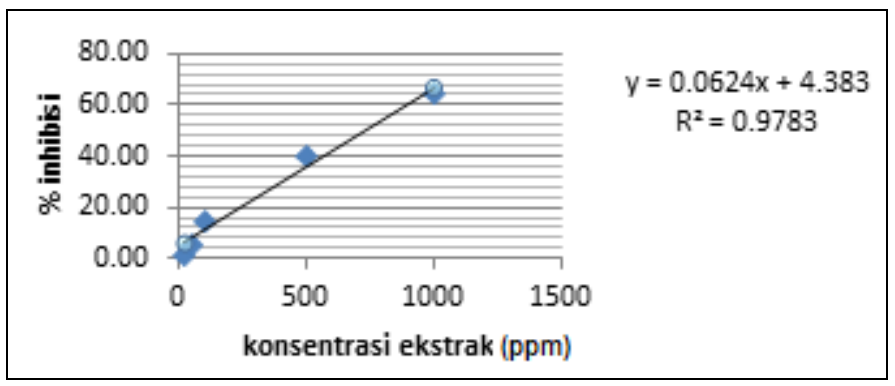

Gambar 2. Grafik antara konsentrasi ekstrak etanol kulit durian vs \%inhibisi enzim.

5. Uji daya hambat acarbose terhadap aktifitas enzim

Acarbose adalah salah satu jenis obat antidiabetes terutama diabetes tipe 2 yang digunakan untuk menghambat kerja enzim $\alpha$-amilase sehingga menunda pencernaan karbohidrat, mengurangi absorpsi glukosa sehingga mencegah naiknya glukosa plasma postprandial (Sales et al., 2012). Obat ini membantu menurunkan kadar gula dalam darah setelah makan (DiNicolantonio et al., 2015). Pada terapi diabetes, penggunaan acarbose bisa dikonsumsi bersama dengan obat lainnya seperti insulin, metformin, dan sulfonilurea sesuai dengan resep dokter (DiNicolantonio et al., 2015).

Uji daya hambat acarbose terhadap enzim $\alpha$-amilase ini dilakukan sebagai pembanding atau kontrol positif, sekaligus sebagai acuan pada tahapan kerja selanjutnya. Pengujian ini dilakukan dengan menambahkan seri konsentrasi ke dalam sampel. Adapun seri konsentrasi acarbose yang digunakan adalah 0,$5 ; 1 ; 1,5 ; 2$, dan 2,5 ppm. Absorbansi yang sudah didapatkan kemudian digunakan untuk menghitung nilai inhibisi 
acarbose terhadap aktifitas enzim $\alpha$ amilase. $I_{50}$ yang dihasilkan dari perhitungan diperoleh sebesar 0,453 ppm. Adapun grafik antara konsentrasi acarbose terhadap \% inhibisi enzim dapat dilihat pada Gambar 3.

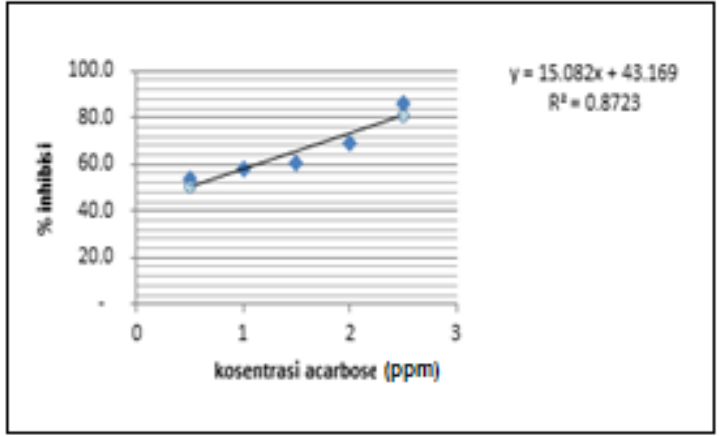

Gambar 3. Grafik konsentrasi acarbose vs \% inhibisi.

\section{Perhitungan combination index}

Perhitungan combination index atau $\mathrm{Cl}$ digunakan untuk melihat reaksi kombinasi antara dua senyawa zat aktif yang digunakan secara bersamaan, terutama dalam menentukan terapi pendamping. Combination index dibagi menjadi 3 kategori efek yang dihasilkan, yaitu efek sinergisme, aditif, dan antagonis. Kategori sinergisme merupakan efek yang saling suportif/mendukung antar 2 senyawa kombinasi yang akan memperbaiki hasil terapi, diwujudkan dengan nilai $\mathrm{Cl}$ nya $<1$. Efek aditif adalah efek kombinasi dari dua obat ketika dikonsumsi secara bersamaan efeknya sama dengan ketika masingmasing obat yang diberikan tunggal ditunjukan dengan nilai $\mathrm{Cl}=1$. Efek antagonis merupakan efek yang terjadi ketika satu obat mengganggu dengan aksi lain, menyebabkan netralisasi atau penurunan efek salah satu obat, ditunjukkan dengan nilai $\mathrm{Cl}>1$.

Pengujian combination index dilakukan dengan cara melihat daya hambat enzim ketika diberikan sediaan kombinasi antara ekstrak etanol kulit durian dan acarbose. Konsentrasi yang diberikan adalah $\begin{array}{lllll}\text { antara } & 1 / 4 & I_{50} & \text { dari ekstrak }\end{array}$ dikombinasikan dengan $\quad 1 / 4 \quad I_{50}$ dari 
acarbose, $1 / 2 I C_{50}$ ekstrak dengan $1 / 2 I C_{50}$ acarbose, $3 / 4 I_{50}$ ekstrak dengan $3 / 4 I_{50}$ acarbose, dan $\mathrm{IC}_{50}$ ekstrak dengan $\mathrm{IC}_{50}$ acarbose. Hasil dari perhtungan combination index dapat dilihat pada Tabel 2.

Tabel 2. Nilai $\mathrm{Cl}$ antara ekstrak dengan acarbose

\begin{tabular}{lll}
\hline Konsentrasi Ekstrak & Konsentrasi Acarbose & Nilai Cl \\
\hline $1 / 4$ IC50 & $1 / 4$ IC50 & 2,001 \\
$1 / 2$ IC50 & $1 / 2$ IC50 & 2,00 \\
$3 / 4$ IC50 & $3 / 4$ IC50 & 1,99 \\
IC50 & IC50 & 2,00 \\
\hline
\end{tabular}

Berdasarkan pengamatan dan perhitungan combination index antara konsentrasi, diperoleh nilai $\mathrm{Cl}$ $>1$, sehingga termasuk dalam kategori berefek antagonis. Efek tersebut merupakan efek yang terjadi ketika satu obat mengganggu dengan aksi lain, menyebabkan netralisasi atau penurunan efek salah satu obat. Berdasarkan hasil tersebut penggunaan antara ekstrak etanol kulit durian tidak direkomendasikan untuk digunakan secara bersamaan dengan acarbose.

\section{Simpulan}

Berdasarkan penelitian yang
sudah dilakukan dapat disimpulkan
bahwa efek kombinasi antidiabetik
antara ekstrak kulit durian dan acarbose
dengan perhitungan combination index

dalam penghambatan kerja enzim $\alpha$ amilase adalah antagonis.

\section{Daftar Pustaka}

Anggraeni, E.V. dan Anam, K. 2016. Identifikasi kandungan kimia dan uji aktifitas antimikroba kulit durian (Durio Zibethinus $\mathrm{M}$ ). Jurnal Kimia Sains dan Aplikasi, 19(3):87-93.

Anindyajati, Sarmoko, Putri, D.D.P., Hermawan, A., Meiyanto, E. 2010. Combination of Solanum nigrum L. herb ethanolic extract and doxorubicin performs synergism on T47D breast cancer cells line. Indonesian Jurnal of Cancer Chaemoprevention, 1(2):78-84.

Cummings, J. dan Mann, J. 2009. Carbohydrates, di dalam Essentials of Human Nutrition. Ed. Mann, J., Truswell, A.S. Newyork: Oxford University Press. pp. 35-71. 
DiNicolantonio, J.J., Bhutani, J., O'Keefe. J.H. 2015. Acarbose: safe and effective for lowering postprandial hyperglycaemia and improving cardiovascular outcomes. Open Heart, 2(1):e000327.

Elmaniar, R. Aktivitas penghambatan enzim $\alpha$-glukosidase oleh ekstrak etanol umbi ubi jalar ungu (Ipomoea batatas L.). Skripsi. Fakultas Farmasi, Universitas Muhammadiyah Surakarta.

Jaitrong, S., Rattanapanone, N., Manthey, J.A. 2006. Analysis of the phenolic compound in longan (Euphoria Longan Lour.) Peel. Proceedings of the Florida State Horticultural Society, 119:371- 375.

Kasiviswanath, R., Ramesh, A., Kasiviswanath, K.E. 2005. Hypoglicemic and antihyperglicemic effect of Gmelina asiatica Linn. in normal and in alloxan induced diabetic rats. Biological \& Pharmaceutical Bulletin, 28(4):729-732.

Murray, R.K., Granner, D.K., Rodwell, V.W. 2009. Biokimia Harper. Edisi 27. Jakarta: EGC.
Nelson, D.L. dan Cox, M.M. 2008. Lehninger Principles of Biochemistry. United States: W. H. Freeman.

Perkeni. 2011. Konsensus Pengelolaan dan Pencegahan Diabetes Melitus Tipe 2 di Indonesia. Jakarta: Perkeni.

Sales, P.M., Souza, P.M., Simeoni, L.A., Silveira, D. 2012. $\alpha$-amylase inhibitors: a review of raw material. Journal of Pharmacy \& Pharmaceutical Sciences, 15(1):141-183.

Santoso, P.J. 2012. 1001 Manfaat Durian untuk Kesehatan. http://balitbu.litbang.deptan.go. id/ind/index.php/beritamainmenu-26/13-infoaktual/ 339-1001-manfaat-durianuntukkesehatan. Data diakses pada 19 Oktober 2012.

[WHO] World Health Organization. 2013. Diabetes.

http://www.who.int/topics/diab etes_mellitus/en/. Data diakses pada 9 November 2018. 